\title{
The Ongoing Confusion Over Ongoing Royalties $^{\dagger}$
}

\author{
Mark A. Lemley*
}

\section{INTRODUCTION}

In eBay Inc. v. MercExchange, L.L.C., the United States Supreme Court correctly concluded that courts had both the power and the responsibility to decide whether a successful patent owner needed injunctive relief and whether the imposition of that relief would unduly harm either the defendant or the public. ${ }^{1}$ The Court's application of the traditional four-factor equity test led, for the first time, to a significant number of cases in which courts found patent infringement but refused to enjoin continued infringement. That, in turn, has raised the question "what happens then?"

As a matter of policy, the basic answer seems clear: while the patentee can't enjoin infringement, the infringer should have to pay for the right to continue infringing. But that answer conceals three subsidiary questions. First, do courts have the authority to award an ongoing royalty? Second, who decides what that royalty should be? Finally, how should that royalty be calculated? To date, courts have spent little time thinking about the first and second questions. While they have addressed the third question, they haven't done so in a satisfactory manner. In this article, I endeavor to answer these questions.

\section{AUthority TO ORDER ONGOING ROYALTIES}

Section 283 provides that upon a finding of infringement, a court "may grant injunctions in accordance with the principles of equity."2 Section 284 requires a court to award damages "adequate to compensate for the infringement, but in no event less than a reasonable royalty." 3 The traditional understanding of these remedial provisions is that section 283 operates prospective-

$\dagger$ (C) 2011 Mark A. Lemley.

* William H. Neukom Professor, Stanford Law School; partner, Durie Tangri LLP. Thanks to Colleen Chien, Chris Cotropia, Tom Cotter, Daralyn Durie, Jeanne Fromer, Rose Hagan, Paul Janicke, Amy Landers, Peter Lee, Brian Love, Mike Meurer, Christopher Newman, and participants in conferences at Stanford Law School and the University of Missouri School of Law for comments on a prior draft.

1. 547 U.S. 388, 394 (2006) (holding that injunctive relief was not automatic in patent cases, but must be analyzed subject to the traditional equity test for injunctive relief).

2. 35 U.S.C. $§ 283$ (2006).

3. Id. $\S 284$. 
ly, while section 284 operates retrospectively. ${ }^{4}$ That is, patentees are entitled to damages to compensate them for past acts of infringement and to an injunction that prevents any future infringement.

Ebay throws this basic remedial structure into disarray by holding that injunctions against future infringement aren't always appropriate. ${ }^{5}$ In the wake of $e$ Bay, courts largely have granted injunctive relief to plaintiffs who practice the patent or otherwise participate in the market, but not to nonpracticing entities (NPEs). ${ }^{6}$ If NPEs can't obtain injunctions against future infringement, what remedy do they have against such infringement?

One possible answer is "none." Paul Janicke suggests that courts have no statutory authority to award ongoing royalties to prevailing patentees in the form of a compulsory license. ${ }^{7}$ Tomás Gómez-Arostegui argues in an historical tour-de-force that under the old English system, equity courts did not grant prospective financial rewards and that under recent Supreme Court decisions, federal courts exercising their equity power cannot order any awards that were not available in traditional English equity. ${ }^{8}$ GómezArostequi also points out that some courts applying a related statute involving patent suits against the government ${ }^{9}$ have read it to award only retrospective relief. ${ }^{10}$ Combining the work of these scholars, one might conclude that patentees who cannot obtain injunctive relief have no recourse in either law or

4. See Daniel R. Cahoy, Treating the Legal Side Effects of Cipro(R): A Reevaluation of Compensation Rules for Government Takings of Patent Rights, 40 AM. BuS. L.J. 125, 130-31 (2002).

5. eBay Inc., 547 U.S. at 394.

6. See U.S. Patent Litigation Statistics, PATSTATs, http://patstats.org/Pat stats2.html (follow "Post-eBay Permanent Injunction Rulings in Patent Cases" hyperlink) (collecting cases decided since eBay) (last visited Aug. 25, 2011). The Court in $e B a y$ warned against the creation of bright-line rules regarding entitlement to injunctive relief. eBay Inc., 547 U.S. at 393. This makes it a bit ironic that the effect of $e$ Bay has been so categorical. But the results have come not from the application of a bright-line rule, but rather from the fact that non-practicing entities have not been able to come up with a plausible theory for why they can't be adequately compensated by money damages. See Miranda Jones, Permanent Injunction, A Remedy by Any Other Name Is Patently Not the Same: How Ebay v. Mercexchange Affects the Patent Right of Non-Practicing Entities, 14 GEO. MASON L. REV. 1035, 1052-53 (2007).

7. Paul M. Janicke, Implementing the "Adequate Remedy at Law" for Ongoing Patent Infringement After eBay v. MercExchange, 51 IDEA 163, 176 (2011). But cf. Daniel A. Crane, Intellectual Liability, 88 TEX. L. REV. 253, 256-57 (2009) (discussing ongoing royalties as a form of liability rule regime).

8. H. Tomás Gómez-Arostegui, Prospective Compensation in Lieu of a Final Injunction in Patent and Copyright Cases, 78 FordHAM L. REV. 1661 (2010). See infra notes 10, 16, 24, 27 and accompanying text (further discussing this theory and its limitations).

9. 28 U.S.C. $\S 1498$ (2006) (patentees are entitled to "reasonable and entire compensation" from government infringers).

10. Gómez-Arostegui, supra note 8, at 1710-11. 
equity, at least in their current lawsuit. While some may use this conclusion as a reason to argue for injunctive relief (on the theory that otherwise plaintiffs get nothing), taking this approach seriously in the wake of $e$ Bay may present a bleak prospect for prevailing patent plaintiffs: no injunction and no ongoing royalty.

If courts in fact have no authority to grant ongoing royalties, one possible workaround is to file successive lawsuits to obtain past damages for each new period of infringement. ${ }^{11}$ A district court in Texas has taken this approach, declining to award ongoing royalties in lieu of damages, instead ordering the plaintiff to file a new lawsuit for damages based on the ongoing infringement. ${ }^{12}$ Because remedies for future infringement become remedies for past infringement with the passage of time, the filing of a successive array of suits could allow the award of damages for each new period. ${ }^{13}$ And it would have the advantage of providing courts an opportunity to revisit the decision to deny an injunction should circumstances change. Still, it seems odd to say that the only possible solution is to doom the parties, Zeno-like, to an endless succession of lawsuits presenting the same issue and leading (hopefully, at least) to the same outcome.

Courts need not resort to such a trick, however. Ongoing royalty awards should be available under one of two theories. First, section 284 arguably gives courts the authority to award forward-looking as well as backwardlooking damages. The statute not only permits but also requires courts to award "damages adequate to compensate for the infringement." Motors Corp. v. Devex Corp., the Supreme Court gave the statute a broad reading, finding Congress's purpose to have been "affording patent owners complete compensation." 15

The statute does not identify what "the infringement" is. GómezArostegui assumes that the term refers only to past infringement, ${ }^{16}$ but it isn't necessarily so limited. If a defendant infringes over a period of ten years, seven before the judgment and three after the judgment, one possible reading of the statute is that all of the defendant's sales of the same product are "the infringement" for which the patentee must be compensated. While damages are generally backward-looking, the law in many circumstances gives forward-looking damages based on estimates of losses caused by past acts of infringement. Courts will, in appropriate circumstances, grant damages based on the consequences for future market relationships of past acts of patent infringement, compensating patent owners for future lost sales resulting from

11. For a discussion of how this might work, see Janicke, supra note 7, at 174.

12. z4 Techs., Inc. v. Microsoft Corp., 434 F. Supp. 2d 437, 444 (E.D. Tex. 2006).

13. See Janicke, supra note 7 , at 167 (noting this as an option).

14. 35 U.S.C. $\$ 284$ (2006).

15. 461 U.S. 648, 655 (1983).

16. Gómez-Arostegui, supra note 8, at 1683-84. 
the inability to grow fully because of past infringement. ${ }^{17}$ Similarly, tort law compensates plaintiffs exposed to toxic chemicals for an increased risk of cancer rather than requiring plaintiffs to wait and see if they develop cancer before suing. ${ }^{18}$

True, there is a difference between compensating patentees for predicted future consequences of patent infringement and compensating patentees for actual future infringement when it occurs. But the step from one to the other is not that large. Trade secret law expressly compensates for future infringement, ${ }^{19}$ as does real property law. ${ }^{20}$ Tort law compensates plaintiffs for expected future losses in the form of lost income, future pain and suffering, and the like. ${ }^{21}$ Patent law could do so as well, using section 284 as authority. ${ }^{22}$ Even the routine grant of post-verdict interest in patent cases is an example of a monetary award based on future losses, albeit ones caused by past infringement. ${ }^{23}$ Whether or not the Federal Circuit will embrace this authority is unclear, given its rejection of ongoing damages in patent suits against the government. ${ }^{24}$ But a fair reading of section 284 suggests it could.

Equity provides a second theory under which courts could award ongoing royalties in patent cases. Courts have the general power in equity to order accountings and constructive trusts. ${ }^{25}$ Courts have recognized and applied

17. See, e.g., Brooktree Corp. v. Advanced Micro Devices, Inc., 977 F.2d 1555, 1581 (Fed. Cir. 1992) (permitting lost profits awards based on projected future as well as past losses); Lam, Inc. v. Johns-Manville Corp., 718 F.2d 1056, 1058 (Fed. Cir. 1983) (same).

18. See Norfolk \& W. Ry. Co. v. Ayers, 538 U.S. 135, 141 (2003).

19. UNIF. TRADE SECRETS ACT § 2(b) (1985).

20. See RESTATEMENT (SECOND) TORTS § 930(1)-(2) (1979) (permitting (and in some cases even requiring) a land owner faced with repeated trespasses to recover damages for future as well as past invasions of his property).

21. See JAMES M. FISCHER, UNDERSTANDING REMEDIES $§ \S 9.1-.2$ (2d ed. 2006).

22. Changes in a defendant's product present a different issue. It is reasonable to conclude that the sale tomorrow of a product identical to one determined to infringe yesterday is itself an infringement of the patent. By contrast, courts should not generally predict that products will infringe a patent if those products differ in any substantial way from ones that have previously been found infringing. TiVo, Inc. v. Echostar Corp., 646 F.3d 869, 881-82 (Fed. Cir. 2011) (en banc).

23. See, e.g., Transmatic, Inc. v. Gulton Indus., Inc., 180 F.3d 1343, 1348 (Fed. Cir. 1999).

24. See Gómez-Arostegui, supra note 8, at 1710-11.

25. See, e.g., Root v. Lake Shore \& M.S. Ry. Co., 105 U.S. 189, 207 (1882) ("When, . . relief was sought which equity alone could give . . . in order to avoid a multiplicity of suits and to do complete justice, the court assumed jurisdiction to award compensation for the past injury, not, however, by assessing damages, which was the peculiar office of the jury, but requiring an account of profits . . ."); $c f$. Bowen v. Massachusetts, 487 U.S. 879, 910 (1988) ("[E]ven if the District Court's orders are construed in part as orders for the payment of money by the Federal Government to the State, such payments are not 'money damages' ....."). 
this authority in many situations. For instance, they have required an individual who wrongly patented an invention made by another to hold the profits from that patent in constructive trust for the true inventor. ${ }^{26}$ This equity power easily could justify the award of ongoing royalties. Strictly speaking, such equity awards are not damages, but they serve the same purpose: to compensate the patentee for injury that would otherwise go unremedied. ${ }^{27}$

In short, while the question is not free from doubt, there are reasonable arguments for treating ongoing royalties as within either the law or the equity power of the courts rather than resorting to a series of continuing lawsuits for past damages. Courts seem to agree that at least some authority exists for such an award; those courts that deny injunctive relief overwhelmingly award an ongoing royalty in its place.

\section{Who Sets THE ONGOING RoYALTY?}

Ongoing royalty awards almost always are set by the district judge as part of post-trial briefing. ${ }^{28}$ The Federal Circuit generally endorsed this approach in both Paice LLC v. Toyota Motor Corp. and Amado v. Microsoft Corp. $^{29}$ In Paice, the Federal Circuit grounded the court's authority to do so in equity; it did not consider whether section 284 could justify ongoing royalties as an award of damages. ${ }^{30}$

26. Tronzo v. Biomet, Inc., 156 F.3d 1154, 1161 (Fed. Cir. 1998) (approving constructive trust under patent law); Arachnid, Inc. v. Merit Indus., Inc., 939 F.2d 1574, 1578 (Fed. Cir. 1991) (approving equitable accounting under patent law); Papazian v. Am. Steel \& Wire Co. of N.J., 155 F. Supp. 111, 117 (N.D. Ohio 1957) ("An owner of the equitable title may seek redress against an infringer in a court of equity. If he has been fraudulently induced to part with this title, he may sue in equity for rescission of the transfer and if successful may obtain full redress for infringement by way of injunction, accounting, declaration of trust, or other forms of equitable relief.").

27. While Gómez-Arostegui argues that there were no precise analogues to ongoing royalty awards in English chancery law, that is not the right question even under the most restrictive Supreme Court equity case. See Grupo Mexicano de Desarrollo S.A. v. Alliance Bond Fund, Inc., 527 U.S. 308 (1999) (holding that the debate over equity powers should be conducted by Congress, not the courts). Rather, the question is whether the equitable remedy is of a type traditionally granted in equity, as opposed to an entirely new sort of remedy. Accountings for profits and constructive trusts were well-established in equity, and indeed an accounting for profits was a statutory remedy in patent law until 1946. See, e.g., Water Techs. Corp. v. Calco, Ltd., 850 F.2d 660, 673 (Fed. Cir. 1988).

28. See John M. Golden, Principles for Patent Remedies, 88 TEX. L. REV. 505, $542 \&$ n.211, 543 (2010).

29. See Amado v. Microsoft Corp., 517 F.3d 1353, 1361-62 (Fed. Cir. 2008); Paice LLC v. Toyota Motor Corp., 504 F.3d 1293, 1314 (Fed. Cir. 2007).

30. See Paice, 504 F.3d at 1315; the case contains no discussion of 35 U.S.C. $\S$ 284. 
The source of authority bears directly on the question of who should set the ongoing royalty. Patent damages are legal remedies that are subject to the Seventh Amendment. ${ }^{31}$ Consequently, those remedies must be set by the jury, assuming one is requested (and one virtually always is). ${ }^{32}$ So, if the basis for awarding ongoing royalties lies in section 284, those royalties must be assessed by the jury. ${ }^{33}$ By contrast, if the question is one of equity, courts have the power (and ultimately the responsibility) to set the award. While courts can convene advisory juries on equitable questions, ${ }^{34}$ they cannot abdicate their ultimate decision-making responsibility to the jury.

District courts, not juries, usually set ongoing royalties. Perhaps this practice reflects an (unexpressed) conclusion that the award of ongoing royalties cannot be considered a measure of damages. More likely, this system reflects the practical realities of timing. In most cases, jurors award damages as part of an overall ruling on patent validity and infringement. Then they go home. By the time the judge rules on whether the patentee is entitled to an injunction, it is too late to send the ongoing royalties question back to the same jury. Judges may be reluctant to convene a second jury just to decide the ongoing royalty question. ${ }^{35}$

\section{Calculating the Ongoing Royalty}

Setting an ongoing royalty might seem an impossible task - a prediction of the future. Measuring damages based on projected future sales does require a certain amount of speculation. But patent damages regularly involve even more speculative conclusions. For example, lost profits awards require the recreation of a hypothetical world in which the court uses economic evidence to try to predict what would have happened but for the infringement.

31. U.S. CONST. amend. VII

32. See Janicke, supra note 7, at 185-86. A vast majority of patent cases today are tried to a jury. See, e.g., FY2009 Patent Case Dispositions by District Courts, PATSTATS, http://patstats.org/Patstats2.html (follow "2009 fiscal year disposition modes for patent cases" hyperlink) (last visited July 10, 2011). The notable exceptions are pharmaceutical cases against generics under 35 U.S.C.A. § 271(e)(2) (West Supp. 2011), where damages are not at stake and so no jury trial right is implicated, and cases against the federal government. In 2004, only $18 \%$ of patent trials were to a judge rather than a jury. Thomas H. Adolph, Some Current Patent Infringement Case Statistics, MARTINDALE-HubBLE (Nov. 10, 2006), http://www.martindale.com /litigation-law/article_Jackson-Walker-LLP_257520.htm (citing to data collected by Professor Paul Janicke).

33. Indeed, as we will see in Part IV, there is a reasonable argument that they would have to be assessed by the same jury that awarded past damages.

34. See, e.g., Transmatic, Inc. v. Gulton Indus., Inc., 180 F.3d 1343, 1345 (Fed. Cir. 1999).

35. As I note in Part IV, this problem could be solved if the jury was asked to identify an ongoing royalty as well as past damages. 
Lost profits cases consider not just provable sales lost to the infringer, but also issues such as how an infringer's customers would split between different suppliers, whether the patentee would have made sales of unpatented products normally associated with the patented invention, how the patentee's cost structure or market share would have changed but for the infringement, and how that change would have affected future sales. ${ }^{36}$ Reasonable royalty awards also involve speculation: what would the plaintiff and defendant have agreed to as a royalty if they had decided to agree, rather than spending $\$ 5$ million per side in legal fees to litigate the case all the way to trial? ${ }^{37}$

Further, courts can limit the speculative nature of ongoing royalty awards. A lump-sum royalty award for future infringement does require significant speculation. It requires a prediction of how many infringing products will be sold in the remaining life of the patent, the price at which they will be sold, and the percentage of that price the patentee would be willing to pay. Because each of those factors can vary over time, a forward-looking lumpsum award is unlikely to accurately capture the future injury to the patentee. A per-unit dollar royalty is somewhat better, because a court does not need to accurately estimate how many products the defendant will sell; the defendant simply pays a dollar amount each quarter based on what it actually did sell. ${ }^{38}$ But a per-unit dollar royalty is vulnerable to changes over time in the price or value of the product; a $\$ 25$ royalty on a $\$ 1000$ product becomes more onerous if the price of the product drops to $\$ 200$ over time and a better deal if the price increases to $\$ 2000$. The best option is an ongoing percentage royalty, which obviates the need to predict either the quantity sold or the price. It is still a prediction - the relative value of the patented technology to the other components of the defendant's product may change over time - but it is the best prediction we have. And awarding ongoing royalties seems a better option than presiding over an endless stream of lawsuits between the same parties.

Finally, a court setting an ongoing royalty after a finding of infringement is not writing on a blank slate. A jury has already set a reasonable roy-

36. See Panduit Corp. v. Stahlin Bros. Fibre Works, Inc., 575 F.2d 1152, 1156 (6th Cir. 1978).

37. Am. Intell. Prop. L. Ass'N, 2009 Report of the Economic Survey 29 (2009) (listing typical costs of litigation for IP cases).

38. Continuing royalties have the additional advantage of taking full account of design-around possibilities. A defendant that has already paid damages up front will have no incentive to design around the patent, while a defendant who must pay a royalty for future infringing products will internalize the true marginal cost of making those products, and so will have an incentive to design around the patent if it is efficient to do so.

On the other hand, quarterly payments based on actual sales require continuing court oversight and depend on the ability of the patentee or the court to obtain accurate sales information from the defendant. 
alty for past damages. ${ }^{39}$ According to black-letter patent law, a reasonable royalty represents the rate a willing buyer and a willing seller would have agreed upon if they had known that the patent was valid and infringed. ${ }^{40}$ Conveniently, that determination is precisely what an ongoing royalty in lieu of an injunction is supposed to represent: what the parties would be willing to agree on now that they know the patent is valid and infringed. Thus, the answer to how to set the ongoing royalty seems straightforward: it is the royalty the jury set for past damages assuming validity and infringement. Ideally, the jury will have awarded past damages in the form of a percentage royalty, and we should encourage awards in that form. If so, the judge need only impose the same royalty rate on a going-forward basis. Even if the jury didn't do so, the court will usually be able to determine the implicit royalty rate from the testimony and the dollar award actually given. ${ }^{41}$

One complication is whether the defendant, having lost the suit, is now a willful infringer, giving the judge discretion to treble the ongoing royalty rate, as the district court did in Amado v. Microsoft Corp. ${ }^{42}$ The logic seems straightforward: if I now know that I am infringing a valid patent, and I continue to do it, surely I am a willful infringer. Nonetheless, the Federal Circuit rejected that conclusion in Amado, ${ }^{43}$ and was probably right to do so. If a court has decided that the defendant should be allowed to continue to sell the infringing product because enjoining its sale imposes too great a hardship on either the defendant or the public, it seems odd to then punish the defendant for doing the very thing the court just permitted. The question is not free from doubt; awarding treble ongoing royalties might be a middle ground between merely compensating the patentee and enjoining the product altogether. The punitive nature of treble royalties would encourage the defendant to de-

39. See Stephen M. Ullmer, Note, Paice Yourselves: A Basic Framework for Ongoing Royalty Determinations in Patent Law, 24 BeRKELEY TECH. L.J. 75, 95 (2009). Essentially every non-Hatch-Waxman case involves a past damage award, because it is almost unheard-of for a defendant to stop producing its product pending trial merely because it has been sued. Even if it did, it would frequently owe damages for sales made after constructive notice of the patent but before it ceased production. While some damage awards involve lost profits, not reasonable royalties, those cases all involve patentees that participate in the market, and so they are likely to lead to injunctions rather than ongoing royalties. See Christopher S. Marchese, Patent Infringement and Future Lost Profits Damages, 26 ARIZ. ST. L.J. 747, 760-62 (1994).

40. See Lucent Techs., Inc. v. Gateway, Inc., 580 F.3d 1301, 1324-25 (Fed. Cir. 2009).

41. That is certainly true of per-unit royalties, where the calculation is simply the per-unit royalty divided by the cost of the unit. $C f$. Mark A. Lemley \& Carl Shapiro, Patent Holdup and Royalty Stacking, 85 TEX. L. REV. 1991, 2020-21 (2007) (calculating royalty rates in patent cases by backing out the royalty from the dollar award, the number of infringing goods sold, and the price).

42. 517 F.3d 1353, 1361 (Fed. Cir. 2008).

43. Id. at 1362 . 
sign around the patent. ${ }^{44}$ And if the defendant were a willful infringer before trial, undoing that finding in setting ongoing royalties would make little sense. But if ordinary damages adequately compensate the patentee, increasing those damages can only serve a deterrent purpose. In a case in which a court has denied injunctive relief in order not to deter legitimate business conduct unnecessarily, it probably shouldn't be trebling damages merely because of the finding of infringement.

Awarding ongoing royalties, then, should be a straightforward exercise. Curiously, however, Federal Circuit panels addressing the issue seem to believe that the question is entirely different from the issue of past damages. In Paice LLC v. Toyota Motor Corp., the Federal Circuit vacated a district court award of an ongoing royalty of $\$ 25$ per unit, a rate identical to the jury's award of past damages. ${ }^{45}$ The court said that the question of post-verdict royalties was different from pre-verdict royalties and that the parties should have an opportunity to negotiate an agreement post-verdict before the court sets the ongoing royalty. ${ }^{46}$ In Amado v. Microsoft Corp., in which the court rejected an ongoing royalty that was triple the past damages award, the court suggested in a footnote that a new approach was required. ${ }^{47}$ Neither court set a rule for how ongoing royalties were to be calculated in this new approach. The closest the Federal Circuit came to doing so was a footnote in Amado suggesting that the calculation should use the jury's damage award as a floor and the plaintiff's request as a ceiling - and in Amado the ceiling was fifty times the floor. ${ }^{48}$

District courts have tried to apply this new calculus, but the results have not been encouraging. In Paice, for instance, the district court, instructed by the Federal Circuit not to use the jury's $\$ 25$ per unit damages award, fell back on the most reviled patent damages theory in history, ${ }^{49}$ the so-called $25 \%$ rule of thumb. ${ }^{50}$ The district court awarded $25 \%$ of the value of the component

44. Cf. Tim Carlton, The Ongoing Royalty: What Remedy Should a Patent Holder Receive When a Permanent Injunction is Denied?, 43 GA. L. REV. 543, 571-72 (2009) (arguing that the existing royalty rate undercompensates patent owners and that a new, higher rate should be awarded).

45. 504 F.3d 1293, 1312 (Fed. Cir. 2007).

46. Id. at 1315 .

47. Amado, 517 F.3d at 1361,1362 n.2.

48. $I d$. at 1362 n. 2 .

49. See Uniloc USA, Inc. v. Microsoft Corp., 632 F.3d 1292, 1313-15 (Fed. Cir. 2011) (listing the three main criticisms of the rule and holding as a matter of law that it is "fundamentally flawed").

50. See Paice, 609 F. Supp. 2d at 622, 630 (applying the $25 \%$ rule of thumb on remand from the Federal Circuit). There is no such "rule of thumb." The myth of the $25 \%$ rule of thumb came from a single small study of licenses in the 1950s that has long since been debunked. See Gavin Clarkson, Note, Avoiding Suboptimal Behavior in Intellectual Asset Transactions: Economic and Organizational Perspectives on the Sale of Knowledge, 14 HARV. J.L. \& TECH. 711, 718-19 (2001). Fortunately, the 
covered by the patent, raising the post-verdict rate to $\$ 98$ per unit. ${ }^{51}$ In other words, because of the Federal Circuit's instruction, the district court on remand replaced a more reliable calculation of damages with a notoriously unreliable one that quadrupled the original damages award.

The Federal Circuit has offered two reasons for redoing the pre-verdict calculation. First, Paice suggests that parties must be given an opportunity to settle the case once they know the jury's verdict, and a separate damages calculation gives them the opportunity to do so. ${ }^{52}$ Second, Amado suggests that the royalty will be different once parties know that the patent is valid and infringed. ${ }^{53}$

Neither argument is persuasive. Parties may reassess their positions based on new information - the jury verdict. They may decide they want to settle as a result. But we don't need a second damages trial to cause them to do so. Parties can settle cases at any time; the vast majority do so, often on the courthouse steps or on appeal. ${ }^{54}$ They settle cases even in the face of a clear damages award that the defendant would have to pay absent settlement. ${ }^{55}$ In any event, the significant possibility of reversal on appeal ${ }^{56}$ gives the parties plenty of uncertainty over which to bargain even apart from the damages calculation.

The second idea, that ongoing royalties reflect an entirely different calculus from past damages, makes no sense. The ongoing royalty question is the very same question the jury has just resolved: what would a willing buyer and a willing seller who know the patent is valid and infringed have agreed to as a royalty rate? Amado's suggestion that the jury would have come to a different number had it known the patent was valid and infringed ignores the black letter law of reasonable royalties. Juries are already required to assume

Federal Circuit has since laid that "rule" to rest. Uniloc, 632 F.3d at 1315. Ironically, were Paice still ongoing, this change would necessitate yet another remand of the damages award.

51. Paice, 609 F. Supp. at 630. The court modified the award somewhat, reducing the $25 \%$ rate by $1 / 3$ due to the particular factual circumstances. $I d$.

52. Paice v. Toyota Corp., 504 F.3d 1293, 1315 (Fed. Cir. 2007).

53. Amado, 517 F.3d at 1362.

54. See John R. Allison et al., Patent Quality and Settlement Among Repeat Patent Litigants, 99 GEO. L.J. 677, 689 (2011) (finding 84-91\% of patent cases settle depending on case type); Jay P. Kesan \& Gwendolyn G. Ball, How are Patent Cases Resolved? An Experimental Examination of the Adjudication and Settlement of Patent Disputes, 84 WASH. U. L. REv. 237, 259 (2006) (finding approximately 80\% settlement rate).

55. See, e.g., Mark A. Lemley, Contracting Around Liability Rules, 100 CALIF. L. REV. (forthcoming 2012).

56. On the Federal Circuit reversal rate, see Kimberly A. Moore, Markman Eight Years Later: Is Claim Construction More Predictable?, 9 LeWIS \& CLARK L. ReV. 231, 236 (2005) (finding claim construction reversal rate at approximately 35\%); see also David L. Schwartz, Pre-Markman Reversal Rates, 43 Loyola L.A. L. Rev. 1073, 1094 (2010) (finding that the reversal rate has increased over time). 
that the patent is valid and infringed when setting past damages. ${ }^{57}$ There is no reason to think that asking the same question twice should produce different answers in most cases. ${ }^{58}$

Indeed, doing so may even be unconstitutional. The Seventh Amendment guarantees a right to jury trial on certain patent questions, including patent damages. ${ }^{59}$ If section 284 is the basis for awarding ongoing royalties, then ongoing royalties are patent damages that presumably must be set by the jury. ${ }^{60}$ But the lesser-known reexamination clause of the Seventh Amendment provides that "no fact tried by a jury, shall be otherwise reexamined in any Court of the United States, than according to the rules of the common law." 1 Thus, if the factual question is the same for both past and ongoing royalties, the Constitution prohibits having either the court or a second jury reexamine the facts decided by the first jury. ${ }^{62}$

The reexamination clause makes convening a second jury problematic. As noted above, however, courts generally haven't handled ongoing royalties by reconvening juries. Instead, they have ordered ongoing royalties from the bench, perhaps using their equity authority to do so. But the fact that courts are awarding an equitable accounting rather than money damages doesn't free them from the dictates of the Seventh Amendment. Courts may have separate authority to award an equitable accounting, but in doing so they cannot reexamine facts found by the jury in the past damages award. ${ }^{63}$ And because the

57. See Lucent Techs., Inc. v. Gateway, Inc., 580 F.3d 1301, 1325 (Fed. Cir. 2009).

It may be that, while courts pay lip service to the assumption that the licensed patent was valid and infringed, in practice they ignore that requirement. If so, courts are undercompensating in their award of past damages. I have suggested elsewhere that too much reliance on actual licenses poses this risk. See Daralyn J. Durie \& Mark A. Lemley, A Structured Approach to Calculating Reasonable Royalties, 14 LEWIS \& CLARK L. REV. 627, 642 (2010). But if so, the solution is to correct the error artificially depressing past damage awards, not to create a disconnect between past and future royalties.

58. See Thomas F. Cotter, Four Principles for Calculating Reasonable Royalties in Patent Infringement Litigation, 27 SANTA CLARA COMPUTER \& HigH TECH. L.J. (forthcoming 2011). But see Carlton, supra note 44, at 543 (arguing against use of the reasonable royalty rate).

59. U.S. CONST. amend. VII.

60. Paul Janicke makes this point, criticizing cases that have let district judges rather than juries set the ongoing royalty award. Janicke, supra note 7, at 175-76.

61. U.S. CONST. amend. VII.

62. In re Rhone-Poulenc Rorer, Inc., 51 F.3d 1293, 1303 (7th Cir. 1995). But see generally Patrick Woolley, Mass Tort Litigation and the Seventh Amendment Reexamination Clause, 83 IowA L. REV. 499 (1998) (criticizing expansive use of the reexamination clause to prevent bifurcation of liability and damages).

63. $C f$. Shum v. Intel Corp., 499 F.3d 1272, 1279 (Fed. Cir. 2007) (reversing district court ruling on inventorship, an equitable issue, because it prejudged facts in common with state law claims that were legal issues). 
factual question the jury is answering is the same question the court is supposed to answer, a court ordering an accounting cannot lawfully engage in a "separate calculation" designed to replicate the first.

Notably, this reexamination clause problem would infect even the series of subsequent lawsuits that Gómez-Arostegui concludes are the only legitimate alternative. ${ }^{64}$ The jury in the second lawsuit would be reexamining the damages question, just as a factfinder assessing an ongoing royalty would be. The result would be truly bizarre - a new trial in which every issue has already been determined in a legally binding way.

One possible difference is that past damages reflect a reasonable royalty calculated based on the state of affairs at the time infringement began. ${ }^{65}$ Perhaps ongoing royalties should be calculated based on the parties' later knowledge. ${ }^{66}$ But as a practical matter, courts in damages cases allow consideration of subsequent developments in setting their reasonable royalty under the so-called "book of wisdom," so this distinction is largely illusory. ${ }^{67}$

On occasion, the Federal Circuit has found that changed circumstances compel different royalty rates. ${ }^{68}$ The fact that circumstances can change provides a reason to make the past damages measure a presumptive rather than a required basis for the ongoing royalty. Indeed, it may even be possible that lost profits rather than reasonable royalties will be appropriate in the future, should the plaintiff succeed in entering the market. However, to depart from the jury's award, the factfinder should have to determine that circumstances have in fact changed.

Instead of recalculating royalties, a court setting ongoing royalties should do one of two things: ask the jury in its special verdict form to specify the percentage royalty rate and use that rate for an ongoing royalty, or set a royalty rate derived from the trial testimony and the jury's lump-sum damages award. ${ }^{69}$ In either event, the judge's obligation is to conform the ongoing

64. See Gómez-Arostegui, supra note 8, at 1676-77.

65. See Georgia-Pac. Corp. v. U.S. Plywood Corp., 318 F. Supp. 1116, 1120 (S.D.N.Y. 1970), modified sub nom. Georgia-Pac. Corp. v. U.S. Plywood-Champion Papers, Inc., 446 F.2d 295 (2d Cir. 1971).

66. See Carlton, supra note 44, at 571-72.

67. See Sinclair Ref. Co. v. Jenkins Petroleum Process Co., 289 U.S. 689, 698 (1933) (permitting developments occurring after the date of the hypothetical negotiation to inform the damages calculation: "[A] different situation is presented if years have gone by before the evidence is offered. Experience is then available to correct uncertain prophecy. Here is a book of wisdom that courts may not neglect. We find no rule of law that sets a clasp upon its pages, and forbids us to look within.").

68. See, e.g., Applied Med. Res. Corp. v. U.S. Surgical Corp., 435 F.3d 1356, 1361-63 (Fed. Cir. 2006).

69. Alternatively, we could ask the jury to set both past and future royalty rates, though again there must be some justification for setting two different rates.

There is a reasonable argument that if a jury given the choice between a royalty rate and a lump-sum damages number chooses the latter, that lump sum payment represents the patentee's entire compensation for the period of patent infringe- 
royalty to what the jury awarded, not to depart from it, absent proof of circumstances going forward that differ from those the jury considered in setting past damages. The jury's past damages award should be the presumptive basis for the ongoing royalty; a party that wants to depart from that number should have to show why changed circumstances require it.

\section{CONCLUSION}

Law professors love to write papers explaining why the law imposes obstacles to doing either the right thing or the easy thing. This is not such a paper. In this case, the easy solution is not only the right one, but may actually be legally compelled. Patentees who do not qualify for injunctive relief are entitled to ongoing royalties to compensate them for future infringement. Those ongoing royalties for future infringement should be set at the same rate as damages for past infringement. That's easiest to do if the jury awards a royalty percentage. But even if it doesn't, district courts should award a royalty that gives effect to the jury's findings, not one that disregards them.

ment, past and future. After all, when parties to a license agreement negotiate a lump sum payment rather than an ongoing royalty, they generally intend that lump sum payment to represent complete compensation for the term of the patent. See Phillip Mendes, To License a Patent - or, to Assign It: Factors Influencing the Choice, WORLD INTELL. PROP. ORG., http://www.wipo.int/export/sites/www/sme/en/docume nts/pdf/license_assign_patent.pdf (last visited June 27, 2011). No license agreement I have ever read involves a lump sum payment for a period of years and then converts to a running royalty. Thus, in any case in which the jury given the option concludes that a lump sum payment would be the appropriate royalty, the ongoing royalty rate should arguably be zero. Some courts have recently taken this approach. See Personal Audio, LLC v. Apple, Inc., No. 9:09CV111, 2011 WL 3269330, at*1 (E.D. Tex. Aug. 22, 2011). And the Northern District of California Model Patent Verdict Form now asks jurors to determine whether the royalty would have been an ongoing perunit royalty or a single lump-sum payment. U.S. DIST. COURT FOR THE N. DIST. OF CAl., MOdel PATENT JURY InSTRUCTIONS (revised Oct. 1, 2011) available at www.cand.uscourts.gov/filelibrary/5/Model-Patent-Jury-Instructions.pdf. Continuing royalties are not appropriate in the latter case. Id. 